\title{
TERAPI SENAM MATA SEBAGAI UPAYA PREVENTIFMIOPI PADA ANAK DI MASA PANDEMI COVID -19
}

\author{
Siti Nur Solikah ${ }^{1)}$, Kholifah Hasnah ${ }^{2)}$ \\ ${ }^{1,2}$ Politeknik Insan Husada Surakarta \\ e-mail : sitinurs@akperinsanhusada.ac.id
}

\begin{abstract}
ABSTRAK
Dampak dari pandemi COVID-19 merubah situasi pembelajaran anak disekolah dari tatap muka secara langsung menjadi daring dengan media gadget. Penggunaan gadget secara berlebihan pada anak, dikhawatirkan akan menyebabkan terjadinya penurunan ketajaman mata dan beresiko terjadi miopi pada jangka panjang. Hasil survey menunjukkan banyak orang tua yang khawatir pada kondisi mata anak akibat penggunaan gadget. Meningkatnya angka kejadian miopi pada anak usia sekolah selama pandemi COVID-19 menjadi perhatian kusus bagi pemerintah, pendidik dan orang tua, sehingga perlu dilakukan upaya pencegahan terjadinya miopi pada anak. Pemeriksaan mata secara dini dan pemberian intervensi terapi senam mata pada anak perlu dilakukan untuk mencegah terjadinya masalah kesehatan mata. Tujuan penelitian untuk mengetahui efektifitas terapi senam mata dalam mencegah terjadinya resiko miopi anak usia sekolah dasar akibat pemakaian gadget yang berlangsung selama masa pandemi COVID-19. Penelitian menggunakan metode quasy experiment dengan desain penelitian one group pre test and post test without control. Teknik sampling menggunakan purposive sampling yaitu sejumlah 27 anak. Analisa data menggunakan uji $t$-test. Hasil uji analisis paired $t$-test pada data pre dan post terapi senam mata menunjukkan nilai $p$ value $0.000(<0,05)$ artinya terdapat pengaruh terapi senam mata terhadap upaya pencegahan miopi pada anak usia sekolah. Kesimpulannya adalah anak usia sekolah membutuhkan terapi senam mata untuk menjaga kesehatan mata anak tetap optimal di masa pandemi COVID-19.
\end{abstract}

Kata kunci: anak sekolah; miopi; pandemi COVID-19; senam mata

\section{ABSTRACT}

The impact of the COVID-19 pandemic has changed the learning situation of children at school from face-to-face to online with gadget media. Excessive use of gadgets in children is feared to cause a decrease in eye acuity and the risk of myopia in the long term. The survey show that many parents are worried about the condition of their children's eyes due to the use of gadgets. The increasing incidence of myopia in schoolage children during the COVID-19 pandemic is a special concern for the government, educators and parents, so it is necessary to make efforts to prevent the occurrence of myopia in children. Early eye examinations and the provision of eye exercise therapy interventions in children need to be done to prevent eye health problems. The purpose of the study was to determine the effectiveness of eye exercise therapy in preventing the risk of myopia in elementary school age children due to the use of gadgets that took place during the COVID-19 pandemic. The study used a quasi-experimental method with a onegroup pre-test and post-test without control research design. The sampling technique used a purposive sampling of 27 children. Data analysis used paired t-test. The results of paired sample t-test analysis on the pre and post eye exercise therapy data showed $p$ value of $0,000(<0,05)$, this means that there was an effect of eye exercise therapy on efforts to prevent myopia in school-age children. The conclusion was the school-age children need eye exercise therapy to maintain optimal eye health during the COVID-19 pandemic.

Keywords: school-age children; myopia; the covid-19 pandemic; eye exercise 


\section{PENDAHULUAN}

Pandemi COVID-19 terus mewabah sejak bulan Maret 2020 di Indonesia. Situasi ini berdampak pada beberapa kebijakan termasuk pada pola pembelajaran disekolah terkena imbas dari kebijakan pemerintah tentang social distancing untuk pencegahan penularan virus COVID- 19 di Surakarta. Pembelajaran daring telah ditetapkan pemerintah pada seluruh jenjang pendidikan dari TK hingga perguruan tinggi sesuai dengan berkembangnya revolusi industri 4.0. Hal ini membuat para guru menggunakan media gadget dalam pembelajaran daring selama pandemi.

Kebiasaan baru dimasa pandemi COVID-19 telah merubah kehidupan perkembangan anak usia sekolah dasar di Surakarta. Adanya aturan pembelajaran jarak jauh yang berlaku saat ini, membuat semua kegiatan sehari-hari menjadi terbatas hanya dirumah termasuk kegiatan belajar yang biasanya dilakukan di sekolah menjadi terpusat didalam rumah. Guru dan siswa tidak bisa berinteraksi secara langsung dalam proses belajar mengajar karena semua kegiatan tersebut dilakukan secara online. Siswa tidak lagi bisa beraktivitas secara kelompok diluar rumah dengan teman sebanyanya. Sejak pagi sampai petang anak-anak selalu terpapar dengan layar televisi, gadget, maupun komputer. Setelah selesai mengerjakan tugas sekolah biasanya anak-anak bermain game dan membuka aplikasi lainnya untuk mengurangi kejenuhan karena orang tua cenderung membatasi anak beraktifitas diluar rumah selama pandemi COVID-19.

Menurut Anggraeni (2019), pengaruh gadget bagi kesehatan mata diantaranya adalah menyebabkan terjadinya penurunan ketajaman mata, kekeringan pada mata, mata menjadi berair, mengalami sakit kepala bagi penggunannya bahkan menyebabkan kerusakan otak akibat paparan sinar dari layar monitor. Penggunaan gadget secara berlebihan dalam jangka panjang dapat menyebabkan gangguan mata minus (miopi).

Berdasarkan hasil penelitian survei perkembangan miopia pada anak dan remaja di Chongqing China pada tahun 2020, selama pandemi COVID-19 diperoleh data persentase siswa miopia pada tahun 2020 sebesar 55,02\%, lebih tinggi dibandingkan tahun 2019 (44,62\%). Ketajaman visual yang tidak dikoreksi (UCVA, LogMAR, 0,35 \pm 0,42) pada tahun 2020 lebih tinggi dibandingkan tahun 2019, sedangkan di India sebanyak 917 siswa (79\%) mengalami miopi pada bulan Maret dan April tahun 2020 (W. Wang et al., 2021).

Menurut Yulaihah (2018) daya lihat anak sangat dipengaruhi oleh perilaku penggunaan gadget. Banyak faktor yang mempengaruhi daya lihat anak seperti genetik dari orang tua, posisi tiduran saat membaca, jarak dekat dengan monitor/layar, bermain game dan lainnya.

Urgensi dari penelitian ini adalah adanya data Riset Kesehatan Dasar 2013 yang menyatakan bahwa 66 juta dari jumlah anak usia sekolah di Indonesia, telah mengalami gangguan kesehatan mata karena refraksi sebanyak 10\%. Data dari Perhimpunan Dokter Spesialis Mata Indonesia (PERDAMI) mencatat 20\% anak usia sekolah di Indonesia mengalami kelainan mata pada usia dini bahkan $80 \%$ telah tercatat menggunakan kaca mata.

Miopi adalah epidemi yang berkembang yang akan mempengaruhi setengah dari populasi global pada tahun 2050 dan menimbulkan kehilangan penglihatan yang tidak dapat diubah. Hal ini akan mempengaruhi setiap aspek termasuk pendidikan, pekerjaan dan keselamatan. Lebih dari 2 miliar orang di seluruh dunia diperkirakan menderita miopia, yang berpotensi 
menyebabkan terjadinya degenerasi makula, ablasi retina, glaukoma sudut terbuka dan katarak (Hu, Leck and Eaton, 2019).

Salah satu upaya untuk mencegah terjadinya penurunan ketajaman mata pada anak usia sekolah bisa dilakukan dengan latihan gerak mata. Latihan gerak mata sangat mudah dilakukan dimanapun dan kapanpun bagi anakanak usia sekolah karena gerakan terapi senam mata cukup mudah dilakukan. Terapi senam mata bermanfaat untuk merelaksasikan mata yang lelah akibat kebiasaan buruk dalam penggunaan gadget, TV, membaca buku terlalu dekat dan bermain game pada anak usia sekolah. Pemberian latihan terapi senam mata yang dilakukan secara berulang-ulang diharapkan dapat menjadi upaya pencegahan miopi serta memberikan perubahan perilaku pemeliharaan kesehatan mata pada anak dalam mewujudkan perkembangan mata yang optimal di masa tumbuh kembang anak (Anwari et al., 2018).

\section{METODE PENELITIAN}

Penelitian ini merupakan penelitian kuantitatif dengan jenis rancangan pre eksperimen dengan menggunakan pendekatan pretest posttest group without control. Populasi dari penelitian ini adalah seluruh siswa - siswi SD Al-Islam II Jamsaren Surakarta kelas IV berjumlah 120 siswa. Tehnik pengambilan sampel pada penelitian ini dilakukan dengan metode purposiv sampling dimana sampel yang dipakai adalah siswa- siswi kelas IV D (kelas khusus) yang berjumlah 27 siswa terdiri dari laki laki dan perempuan dengan kriteria inklusi: 1)Usia anak 9-12 tahun, 2)Anak menggunakan gadget lebih dari 2 jam perhari dirumah, 3)Anak tidak menggunakan kacamata, 4)Anak tidak sedang menggunakan obat tetes mata, 5)Ibu dan anak bersedia menjadi responden. Kriteria eksklusi penelitian ini adalah: 1)Anak usia kurang dari 9 tahun, 2)Anak menggunakan kaca mata, 3)Anak mengalami gangguan refraksi, 4)Anak menggunakan tetes mata/ obat, 5)Tidak bersedia menjadi responden.

Pada tahap awal sebelum dilakukan penelitian, peneliti melakukan penyuluhan tentang kesehatan mata anak yang berisi tentang kesehatan mata, penggunaan gadget dan demonstrasi terapi senam mata pada ibu responden secara daring melalui google meet. Setiap kali anak melakukan senam mata, ibu menulis kegiatan di lembar observasi yang telah diberikan oleh tim peneliti. Ibu juga bertugas mengawasi perilaku penggunaan gadget dirumah selama masa terapi senam mata. Selanjutnya anak diundang ke sekolah untuk dilakukan pemeriksaan ketajaman mata dan wawancara perilaku penggunaan gadget.

Tahap selanjutnya responden melakukan terapi senam mata dirumah sebanyak 16 kali (2x/minggu) dalam pengawasan orang tua. Pada tahap akhir responden diperiksa kembali ketajaman matanya dan dilakukan wawancara perilaku penggunaan gadget. Pengumpulan data pada penelitian ini dilakukan dengan observasi langsung, wawancara responden dan dokumentasi tertulis.

Alat ukur penelitian menggunakan kuesioner wawancara perilaku penggunaan gadget, pengukuran ketajaman penglihatan dengan snellen card dan lembar observasi visus kesehatan mata, dan pelaksanaan senam mata dirumah menggunakan cheklist observasi.

Alat ukur telah valid dan reliabel. Penelitian ini telah melalui uji etik dengan nomor etical clearance 051/UKH.L.02/EC/IV/2021. Data yang telah terkumpul dilakukan uji normalitas data terlebih dahulu dengan shapiro wilk. Selanjutnya 
dilakukan uji t-test untuk mengetahui pengaruh pemberian intervensi senam mata pada responden.

\section{HASIL DAN PEMBAHASAN}

a. Analisa univariat Tabel 1. Hasil Analisis Karakteristik Jenis Kelamin, UmurDan Riwayat Miopi Keluarga Responden ( $\mathrm{n}=27)$

\begin{tabular}{lll}
\hline Karakteristik & f & $\%$ \\
\hline Jenis Kelamin & & \\
Perempuan & 20 & \\
Laki - laki & 7 & 26 \\
$\quad$ Umur Anak & & \\
9 tahun & 4 & 15 \\
10 tahun & 22 & 81 \\
11 tahun & 1 & 4
\end{tabular}

\section{Riwayat keluarga}

Ada miopi $\quad 6 \quad 22$

Tidak ada miopi 21

(sumber data primer, 2021)

Tabel 1 menunjukkan bahwa jenis kelamin responden paling banyak adalah jenis kelamin perempuan sebanyak 20 anak (74\%) dan sisanya berjenis kelamin laki-laki sebanyak 7 anak (26\%). Berdasarkan data umur paling banyak responden berumur 10 tahun (81\%).

Berdasarkan hasil analisis tabel 1 tersebut, terdapat 6 anak (22\%) mempunyai riwayat keturunan gangguan kesehatan mata (miopi) pada keluarga. Hal ini sejalan dengan hasil konsensus di dunia yang menyatakan bahwa sebagian besar miopi disebabkan oleh faktor keturunan dalam sebuah keluarga. Anak dengan riwayat keluarga penderita miopi mempunyai resiko lebih tinggi menderita miopi dibandingkan anak yang tidak mempunyai riwayat dalam keluarganya (Setyowati et al., 2019).

Tabel 2. Hasil Analisis Karakteristik Ibu $(\mathrm{n}=27)$

\begin{tabular}{lll}
\hline Karakteristik & f
\end{tabular}

\begin{tabular}{ccc}
\hline Umur & & \\
$20-30$ & 19 & 70 \\
$31-40$ & 5 & 19 \\
$41-50$ & 3 & 11 \\
Pendidikan & & \\
SD & 0 & 0 \\
SMP & 6 & 20 \\
SMA & 20 & 67 \\
PT & 4 & 13 \\
Pekerjaan & & \\
Swasta & 5 & 19 \\
Wiraswasta & 4 & 15 \\
PNS & 1 & 4 \\
IRT & 17 & 63 \\
\hline
\end{tabular}

(sumber data primer, 2021)

Tabel 2 menunjukkan bahwa paling banyak ibu responden berumur 20-35 tahun yaitu sebanyak 19 responden (70\%), dengan jenis pekerjaan paling banyak sebagai ibu rumah tangga sebanyak 17 responden (63\%).

Penelitian ini melibatkan ibu sebagai pendamping anak saat melakukan terapi senam mata dirumah. Orang tua terutama ibu berperan dalam mendampingi anak saat menggunakan gadget. Rata-rata wali murid responden adalah ibu rumah tangga sehingga mampu mendampingi dan mengawasi penggunaan gadget dan terapi senam mata pada anak dirumah. Akibat pandemi COVID-19, orang tua dirumah berperan sebagai guru yang diharuskan membimbing siswa belajar dirumah mengerjakan tugas dari guru (Wardani and Ayriza, 2020).

Pada tabel 2 diatas juga menjelaskan data paling banyak ibu berpendidikan tingkat SMA/SMK sebanyak 20 responden (67\%). Pengetahuan seorang ibu sangat diperlukan dalam pengawasan penggunaan gadget sehingga mengurangi dampak negatif penggunaan gadget pada anak selama pandemi covid-19 (Farizal, 2018).

Selama pandemi berlangsung, orang tua terutama ibu bertambah perannya menjadi seorang guru 
dalam rumahnya sendiri. Ibu bertugas membimbing dan mengawasi anakanaknya dalam mengerjakan tugas yang diberikan oleh guru sekolah (Ramadhani, Fathurohman and Fardani, 2020).

Tabel 3. Distribusi frekuensi hasil pemeriksaan ketajaman mata sebelum dan sesudah pelaksanaan terapi senam mata $(n=27)$

\begin{tabular}{lcccc}
\hline Ketajaman & \multicolumn{2}{c}{ pre } & \multicolumn{2}{c}{ post } \\
\cline { 2 - 3 } mata & f & \% & f & \% \\
\hline Normal & 15 & 55 & 20 & 74 \\
Hampir & 8 & 30 & 3 & 11 \\
$\begin{array}{l}\text { Normal } \\
\text { Low }\end{array}$ & 4 & 15 & 4 & 15 \\
Vision & & & & \\
\hline
\end{tabular}

(sumber data primer, 2021)

Berdasarkan hasil analisa data tabel 3, dapat diketahui adanya perubahan hasil pemeriksaan mata pada anak dengan menggunakan Snellen sebelum dan sesudah dilakukan terapi senam mata dirumah. Sebelum dilakukan terapi senam mata hasil pemeriksaan mata anak kategori normal terdapat 15 anak (55\%), kategori hampir normal 8 anak $(30 \%)$ dan terdapat 4 anak (15\%) kategori low vision.

Pemeriksaan ketajaman mata pada anak dapat diukur dengan alat sederhana yaitu dengan snellen card yang mampu mengukur ketajaman mata anak pada jarak 6 meter. Hasil pemeriksaan visus mata yang normal adalah $6 / 6$ yang artinya anak mampu melihat benda dengan jelas pada jarak 6 meter. Penurunan ketajaman mata pada anak dapat menyebabkan gangguan aktivitas belajar siswa (Anggraeni, 2019).

Setelah dilakukan terapi senam mata dirumah selama 16 kali kegiatan, terdapat peningkatan jumlah anak dalam kategori normal terdapat 20 anak (74\%), kategori hampir normal ada 3 anak (11\%) dan kategori low vision tidak mengalami perubahan setelah dilakukan terapi senam mata masih ada 4 anak (15\%).
Berdasarkan hasil kuesioner pada 4 responden yang mengalami low vision mempunyai riwayat genetik ibu/ayah yang mengalami kelainan refraksi mata (miopi) dalam keluarga. Prevalensi miopi pada anak yang orang tuanya mengalami miopi adalah $32,9 \%$. Responden yang memiliki riwayat miopi dalam keluarga memiliki resiko yang lebih besar mengalami miopi dibadingkan responden yang tidak memiliki riwayat keluarga dengan miopi (Musiana, Nurhayati, 2020).

Prevalensi miopia lebih tinggi pada individu yang kedua orang tuanya miopia, menunjukkan bahwa faktor genetik jelas terlibat dalam perkembangan miopia (Cooper and Tkatchenko, 2018).

Bertambahnya responden yang berkategori normal setelah dilakukan terapi senam mata kemungkinan karena selain responden melakukan terapi senam mata dirumah juga karena peran ibu dalam merubah perilaku anak yang benar dalam menggunakan gadget dirumah seperti: pengaturan jarak, frekuensi, pencahayaan pada layar gadget, posisi duduk saat menggunakan gadget dll. Pada penelitian ini Ibu telah mendapatkan pengetahuan dalam penggunaan gadget yang benar pada anak usia sekolah dasar saat dilakukan penyuluhan secara daring sehingga anak menjadi terkontrol perilakunya dalam penggunaan gadget dirumah selama masa terapi senam mata.

Dimasa pandemi seperti ini, pengawasan orang tua sangat dibutuhkan, apabila tidak diawasi anak akan cenderung menggunakan smartphone untuk bermain game atau membuka aplikasi lainnya

(Ramadhani, Fathurohman and Fardani, 2020).

Hal serupa juga diungkapkan oleh Yulaiha (2018) yang menyimpulkan adanya hubungan penggunaan gadget sehari-hari pada anak usia prasekolah dengan ketajaman mata anak. 
Semakin sering anak terpapar gadget maka semakin buruk daya lihat anak (Yulaihah, 2018).

Hasil penelitian di China oleh Wang dkk (2021) menyatakan bahwa pembatasan anak dirumah selama pandemi COVID-19 menyebabkan peningkatan terjadinya miopi pada anak secara signifikan pada anak usia sekolah. Status refraksi anak-anak yang lebih muda lebih sensitif terhadap perubahan lingkungan daripada usia yang lebih tua, mengingat anak-anak yang lebih muda berada dalam periode resiko tinggi terjadi miopi (J. Wang et al., 2021).

b. Uji Normalitas

Uji normalitas data pada penelitian ini menggunakan Shapiro wilk-test karena sampel yang digunakan kurang dari 50 responden. Hasil uji normalitas data sebelum diberikan intervensi senam mata adalah 0,052 dan setelah diberikan intervensi senam mata nilainya adalah 0,095 . Kedua nilai $p>0,05$ artinya data berdistribusi normal sehingga dilanjutkan analisa data dengan uji ttest.

c. Analisa Bivariat

Berikut ini merupakan hasil analisa data dengan t-test untuk mengetahui perbedaan ketajaman mata sebelum dan sesudah diberikan intervensi terapi senam mata pada responden.

Tabel 4. Perbedaan pemeriksaan mata anak sebelum dan sesudah dilakukan intervensi terapi senam mata $(\mathrm{n}=27)$

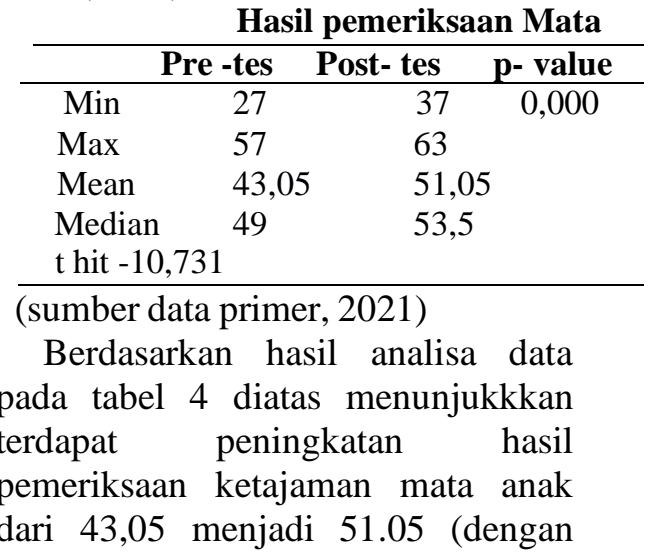

nilai signifikansi $(0,000)$ dengan jumlah nilai selisih adalah 8,0 dengan nilai t hitung 10,731

Berdasarkan tabel 4 hasil analisa uji t-test menunjukkan nilai sig (2 tailed) sebesar 0,000 $(<0,05)$ maka Ho ditolak dan Ha diterima, sehingga dapat disimpulkan bahwa ada perbedaan hasil pemeriksaan ketajaman mata sebelum dan sesudah pemberian intervensi terapi senam mata pada responden.

Hal ini juga berarti bahwa terapi senam mata berpengaruh terhadap ketajaman mata anak usia sekolah dasar, dengan kata lain terapi senam mata ini efektif sebagai upaya preventif miopi pada anak usia sekolah dasar di masa pandemi COVID - 19 di SD Al Islam 2 Jamsaren Surakarta.

Penggunaan gadget yang tidak baik bisa menyebabkan penurunan ketajaman mata dan membuat otot mata menjadi kaku biasanya ditandai dengan mata terasa lelah, penglihatan menjadi buram, penglihatan menjadi ganda, kepala pusing dan rasa tidak nyaman pada okuler saat melihat objek benda dari dekat dan jauh. Beberapa gejala tersebut bisa dicegah melalui gerakan terapi senam mata (Sari Dewi and Novia, 2020). Semakin sering durasi seorang anak terpapar blue light yang dihasilkan dari layar gadget yang digunakan oleh anak, maka semakin tinggi angka kejadian penurunan kesehatan mata pada anak (Riska Wandini, Linawati Novikasari, 2020).

Menurut asumsi peneliti terdapat pengaruh senam mata terhadap ketajaman mata pada anak karena senam mata mampu melatih kembali otot-otot mata anak agar tidak kaku akibat terlalu lama menatap layar gadget. Data kategori low vision maupun kategori hampir normal yang terjadi pada responden disebabkan karena terlalu lama di depan layar gaget sehingga otot mata anak menjadi kaku dan dapat mengakibatkan kurang tajamnya 
penglihatan saat dilakukan pemeriksaan ketajaman mata disekolah. Selain itu juga disebabkan adanya faktor genetik dalam keluarga yang tidak bisa merubah hasil pemeriksaan ketajaman mata sebelum maupun sesudah dilakukan terapi senam mata.

Pada penelitian ini responden melakukan terapi senam mata sebanyak $16 \times(2 \mathrm{x} /$ minggu $)$ dengan pengawasan dari orang tua dirumah, setiap kali anak melakukan terapi senam mata ibu menuliskan pada lembar observasi.

Gerakan senam mata yang dilakukan pada responden penelitian ini mengadopsi dari hasil penelitian Maisal dkk (2020) dan hasil rancangan buku tentang cara menjaga kesehatan mata anak melalui olahraga senam mata yang ditulis oleh Wahyudi dkk (2019) terdiri dari 7 langkah gerakan senam mata selanjutnya disempurnakan menjadi 9 langkah pada gambar berikut:

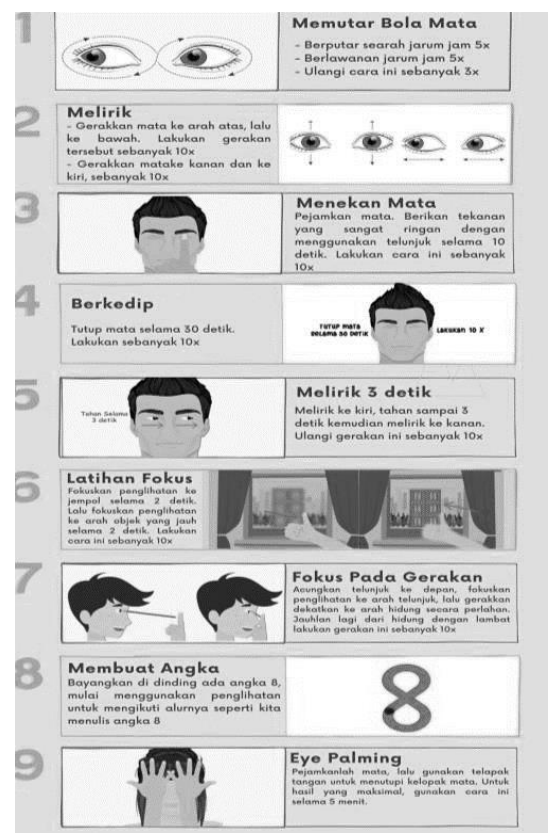

Gambar 1. Sembilan Gerakan Senam Mata Sumber: (Maisal et al., 2020), (Devara, Artawan and Wahyudi, 2019)

Perbedaan pada penelitian yang dilakukan oleh Anwari dkk (2018) dilakukan sebanyak 12 kali kegiatan senam mata pada responden dimana pada akhir penelitian didapatkan hasil perubahan data pada ketajaman mata responden yang signifikan mulai dari pertemuan pertama (visus mata 20/60) sampai pertemuan akhir yaitu pertemuan 12 ( visus mata 39.4/60). Hasil ini menunjukkan bahwa terdapat pengaruh latihan gerak mata dalam meningkatakn ketajaman mata pada anak (Anwari et al., 2018).

Hal ini sejalan dengan hasil penelitian Maisal dkk (2020) pada responden pekerja rambut palsu di kota Kupang, dimana dengan melakukan senam mata secara rutin (4 kali sehari) dalam kelompok selama enam kali pertemuan didapatkan hasil responden mengalami penurunan nilai rata-rata kelelahan pada mata pekerja rambut palsu (Maisal et al., 2020).

National Institute for Occupational Safety and Health (NIOSH) tahun 2008 menyatakan bahwa mata membutuhkan istirahat untuk mengatasi ketegangan pada otot mata. Pengguna dalam menggunakan computer, HP maupun laptop harus mengistirahatkan kedua mata dan mengedipkan bola mata untuk mengelastiskan otot pada mata sehingga tidak dapat menimbulkan gejala Computer Vision Syndrome. Senam mata merupakan teknik yang biasa digunakan agar bola mata terbiasa lentur dan bergerak sesuai dengan jangkauan mata, semakin lebar jangkauan bola mata semakin baik dalam membaca. Terapi senam mata juga bermanfaat dalam mencegah tumor mata hiposfisi, meghilangkan kantung mata dan bengkak dibawah mata, senam mata mampu mengurangi keriput disekitar mata (Intan Putri Arisandi, Gamya Tri Utami, 2018).

\section{KESIMPULAN}

Berdasarkan hasil penelitian dapat disimpulkan:

a. Sebelum dilakukan terapi senam mata hasil pemeriksaan mata anak 
kategori normal terdapat 15 anak (55\%), kategori hampir normal 8 anak $(30 \%)$ dan terdapat 4 anak (15\%) kategorilow vision.

b. Setelah dilakukan terapi senam mata terdapat peningkatan jumlah anak dalam kategori normal terdapat 20 anak $(74 \%)$, kategori hampir normal ada 3 anak (11\%) dan kategori low vision ada 4 anak (15\%).

c. Hasil analisa uji t-test menunjukkan nilai sig (2 tailed) sebesar 0,000 $(<0,05)$ maka Ho ditolak dan $\mathrm{Ha}$ diterima, sehingga dapat disimpulkan bahwa ada perbedaan hasil pemeriksaan ketajaman mata sebelum dan sesudah pemberian intervensi terapi senam mata pada responden, sehingga menghasilkan kesimpulan bahwa terapi senam mata efektif sebagai upaya pencegahan miopi pada anak usia sekolah dasar di SD Al- Islam 2 Jamsaren Surakarta.

\section{SARAN}

a. Orang tua siswa/wali

Orang tua siswa sebaiknya segera memeriksakan anak yang mengalami kategori low vision ke dokter spesialis mata agar mendapatkan penanganan kesehatan mata sedini mungkin. Orang tua siswa sebaiknya selalu mendampingi anak dalam menggunakan gadget sehari hari dirumah.

b. Sekolah

Sekolah sebaiknya membuat program penyuluhan kesehatan pada anak secara berkala dengan mengandeng pihak Puskesmas maupun institusi kesehatan setempat. Sebaiknya di setiap kelas dipasang poster senam mata dan memberlakukan kegiatan terapi senam mata sebagai kegiatan yang wajib dan rutin dilakukan dengan pendampingan oleh guru kelas pada hari tertentu.

c. Bagi peneliti

Kepada peneliti selanjutnya, sebaiknya penelitian tentang pelaksanaan terapi senam mata ini dilakukan dengan menambah jumlah sampel dan meneliti faktor lain yang menyebabkan penurunan tajam penglihatan (visus mata) pada anak usia sekolah.

d. Bagi institusi kesehatan

Melaksanakan program preventif bekerjasama denganpihak sekolah seperti mengadakan pemeriksaan tajam penglihatan secara rutin dan edukasi tentang kesehatan mata secara terjadwal untuk mencegah miopi pada anak untuk mencapai derajad kesehatan yang optimal pada anak.

\section{UCAPAN TERIMA KASIH}

Terimakasih kami ucapkan kepada:

1. Kemendikbud-Ristek yang telah memberikan pendanaan hibah penelitian tahun anggaran 2021.

2. Direktur, LPPM dan rekan-rekan dosen Politeknik Insan Husada Surakarta yang telah banyak membantu selama proses penelitian.

3. Kepala sekolah SD Al Islam 2 Jamsaren Surakarta yang telah memberikan ijin penelitian dan memfasilitasi proses penelitian.

4. Mahasiswa beserta semua pihak yang terlibat dalam penyusunan penelitian.

\section{REFERENSI}

Anggraeni, S. (2019) 'Pengaruh Pengetahuan Tentang Dampak Gadget Pada Kesehatan Terhadap Perilaku Penggunaan Gadget Pada Siswa SDN Kebun Bunga 6 Banjarmasin', Faletehan Health Journal, 6(2), pp. 6468. doi: 10.33746/fhj.v6i2.68.

Anwari, M. et al. (2018) 'Latihan Gerak Mata Untuk Kesehatan Mata: Studi Kasus Pada Keluarga Binaan Di Desa Kemuningsari Lor Kecamatan Panti Kabupaten Jember', The Indonesian Journal of Health Science, p. 155. doi: 10.32528/ijhs.v0i0.1540.

Cooper, J. and Tkatchenko, A. V. (2018) 'A Review of Current Concepts of the Etiology and Treatment of 
Myopia', Eye \& contact lens, 44(4), pp. 231-247. doi: 10.1097/ICL.0000000000000499.

Devara, N., Artawan, C. A. and Wahyudi, A. T. (2019) 'Perancangan Buku Panduan Interaktif Cara Menjaga Kesehatan Mata Melalui Olahraga Senam Mata Untuk Anak Usia 6 - 12 Tahun', DKV Adiwarna, UNIVERSITAS KRISTEN PETRA., 1 No.14, p. 11. Available at: http://publication.petra.ac.id/index.php/d $\mathrm{kv} /$ article/view/8651/7809.

Ekawaty, D. (2018) 'Pengaruh Penggunaan Gadget Terhadap Gangguan Kesehatan Mata Pada Murid Sekolah Dasar Negeri Percontohan Pam Makassar', Patria Artha Journal of Nursing Science, 2(2), pp. 81-87. doi: $10.33857 /$ jns.v2i2.152.

Farizal, B. E. (2018) 'Hubungan Pengetahuan Orang Tua Tentang Penggunaan Gadget Pada Anak Usia 2-5 Tahun Terhadap Dampak Penggunaan Gadget Di Wilayah Kerja Puskesmas Berseri Pangkalan Kerinci Kabupaten Pelalawan Tahun 2018', Menara Ilmu, 12(9), pp. 140147.

Hu, V., Leck, A. and Eaton, J. (2019) 'Community Eye Health J ournal eye health', 33(109), pp. 21-25.

Intan Putri Arisandi, Gamya Tri Utami,

R. N. (2018) 'Efektivitas Senam Mata terhadap Computer Syndrome (CVS)', JOM FKp, 5(2), pp. 520526.

Maisal, F. M. et al. (2020) 'Efektivitas Senam Mata untuk Mengurangi Tingkat Kelelahan Mata pada Pekerja Rambut Palsu', Jurnal Ergonomi Indonesia (The Indonesian Journal of Ergonomic), 6(1), p. 9. doi: 10.24843/jei.2020.v06.i01.p02.
Musiana, Nurhayati, S. (2020)

'Faktor Resiko Yang Berhubungan Dengan Kejadian Miopi Anak Usia Sekolah', 15(1), pp. 71-77.

Rahmawati, Z. D. (2020) 'Penggunaan Media Gadget dalam Aktivitas Belajar dan Pengaruhnya Terhadap Perilaku Anak', TA "LIM: Jurnal Studi Pendidikan Islam, 3(1), pp. 97-113.

Ramadhani, I. R., Fathurohman, I. and Fardani, M. A. (2020) 'Efek Penggunaan Smartphone Masa Pandemi Covid-19 terhadap Perilaku Anak', Jurnal Amal Pendidikan, 1(2), p. 10. Available http://ojs.uho.ac.id/index.php/japend/arti cle/view/13293.

Riska Wandini, Linawati Novikasari, M.K. (2020) 'Hubungan Penggunaan Gadget Terhadap Kesehatan Mata Anak Di Sekolah Dasar Al Azhar I Bandar Lampung', Angewandte Chemie International Edition, 6(11), 951-952., 2(4), pp. 810-819.

Sari Dewi, R. I. and Novia, V. R. (2020) 'Pengaruh Senam Yoga Mata Terhadap Penurunan kelelahan Mata Pada Pekerja Di Divisi Redaksi Padang Ekspres', Jurnal Kesehatan Mesencephalon, 6(1), pp. 37-41. doi: 10.36053/mesencephalon.v6i1.193.

Setyowati, R. et al. (2019) 'Angka Kejadian Miopia Pada Anak Usia Sekolah Dasar Di Kecamatan Banjararum Kabupaten Kulon Progo, Daerah Istimewa Yogyakarta', Journal ofCommunity Empowerment for Health, 2(1), pp. 92-96. doi:10.22146/jcoemph.42913.

Wang, J. et al. (2021) 'Progression of Myopia in School-Aged Children after COVID-19 Home Confinement', JAMA Ophthalmology, 139(3), pp. 293-300. doi:10.1001/jamaophthalmol.2020.6239 
Wang, W. et al. (2021) 'Survey on the Progression of Myopia in Children and Adolescents in Chongqing During COVID-19 Pandemic', Frontiers in Public Health, 9(April), pp. 1-7. doi: 10.3389/fpubh.2021.646770.

Wardani, A. and Ayriza, Y. (2020) 'Analisis Kendala Orang Tua dalam Mendampingi Anak Belajar di Rumah Pada Masa Pandemi Covid-19', Jurnal Obsesi : Jurnal Pendidikan Anak Usia Dini, 5(1), p. 772. doi: 10.31004/obsesi.v5i1.705.

Yulaihah, A. (2018) 'Hubungan Perilaku Penggunaan Gadget Dengan Tingkat Daya Lihat Anak Usia Prasekolah di TK ABA Tegalrejo Yogyakarta', Naskah Publikasi Fakultas Ilmu Kesehatan Universitas 'Aisyiyah. 